\title{
PHYTOTOXICOLOGY VEGETATION
}

ASSESSMENT SURVEY:

CORNWALL ISLAND, ONTARIO

(1993)

\section{JULY 1994}



ISBN 0-7778-2730-1

PHYTOTOXICOLOGY VEGETATION ASSESSMENT SURVEY:

CORNWALL ISLAND, ONTARIO

(1993)

JULY 1994

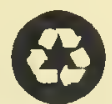

Cette publication technique n'est disponible qu'en anglais.

Copyright: Queen's Printer for Ontario, 1994

This publication may be reproduced for non-commercial purposes with appropriate attribution.

PIBS 3195 

PHYTOTOXICOLOGY VEGETATION ASSESSMENT SURVEY:

CORNWALL ISLAND, ONTARIO

(1993)

\author{
Report prepared by: \\ R. Emerson \\ Standards Development Branch \\ Phytotoxicology Section \\ Ontario Ministry of Environment and Energy
}

Report No: SDB-033-3512-94 



\section{PHYTOTOXICOLOGY VEGETATION ASSESSMENT SURVEY: \\ CORNWALL ISLAND (1993)}

\section{EXECUTIVE SUMMARY}

A Federal-Provincial study with participation by several government agencies, including the Phytotoxicology Section, Ontario Ministry of Environment and Energy (MOEE), was initiated in 1975 to assess the impact of airborne fluoride emissions from the Reynolds Metals Company (RMC), Massena, New York, on the Cornwall Island Indian Reservation (Mohawks of Awkwesasne). Investigations to assess the impact of airborne fluoride emissions from RMC on vegetation on Cornwall Island have been conducted by the Phytotoxicology Section (MOEE) during the growing season annually since 1969, except for 1988 and 1990. This report presents the results of the most recent Phytotoxicology survey conducted in August 1993.

In 1993, the sampling of the regular maple foliage sites and inspections of vegetation for fluoride injury were performed only in August, similar to 1992. The highest degree of foliar contamination and most severe vegetation injury was observed in the vicinity of the south shore bridge area, similar to previous years. Fluoride concentrations in maple foliage were increased slightly in 1993 from 1992. In spite of this marginal increase, the fluoride concentration at the most contaminated Site 1(south shore bridge area) and the mean for all common Manitoba maple sites were amongst the lowest detected. In fact, foliar fluoride concentrations, on average, have fluctuated only marginally since 1978.

The rural Upper Limit of Normal (ULN) guideline for fluoride in tree foliage (15 $\mathrm{ug} / \mathrm{g}$ ) was exceeded at ten sites. The highest fluoride concentration (Site 1) was about ten times the rural ULN.

A few vegetation sites in 1993 had greater injury than in 1992 but, in most cases, the injury was not markedly different from 1992. Sensitive wild grape foliage in 1993 revealed no major change in the degree and extent of fluoride-type foliar injury from the previous year.

Weather conditions could have contributed to the slight increase in fluoride contamination of vegetation on Cornwall Island in 1993. RMC emissions also may have been increased but this has not been verified. Ambient fluoride monitoring on the island was not conducted by Environment Canada in 1992 and 1993. 



\section{PHYTOTOXICOLOGY VEGETATION ASSESSMENT SURVEY: CORNWALL ISLAND, ONTARIO (1993)}

\section{INTRODUCTION}

Vegetation assessment surveys on Cornwall Island in Ontario, in the vicinity of the Reynolds Metals Company (RMC), Massena, New York, have been conducted by the MOEE Phytotoxicology Section during the growing season each year since 1969, with 1988 and 1990 being the only exceptions. The vegetation assessment program is part of an ongoing joint Federal-Provincial study that was established in 1975, with participation by Environment Canada, Agriculture Canada, National Health and Welfare, Indian and Northern Affairs and the Ontario Ministry of Environment and Energy. Between 1969 and 1974, the Phytotoxicology Section conducted annual vegetation surveys and investigated complaints concerning the adverse effects of airborne fluoride emissions on vegetation and cattle on Cornwall Island. The source of the fluoride emissions was identified as the Reynolds Metals Company (RMC), located in Massena, New York. RMC produces aluminum by the aluminum reduction cell process. Emissions from this process include gaseous hydrogen fluoride and particulate sodium aluminum fluorosilicate. The study was broadened in 1975 in view of the transboundary nature of the emissions and their impact on the Awkwesasne Mohawk Indian Reserve on Cornwall Island. The primary objective of the 1993 Phytotoxicology program, similar to previous years, was to determine the degree and extent of fluoride contamination and injury to vegetation on Cornwall Island and to compare these findings with previous results. The results for Phytotoxicology vegetation assessment programs through to 1992 have been previously reported.

\section{VEGETATION ASSESSMENT PROGRAM}

\section{Visual Inspections / Samples for Chemical Analysis}

In 1993, as in 1992, a single-visit survey was conducted on Cornwall Island in midAugust. Vegetation (cherry, maple, sumach, pine, wild and cultivated grape, gladiolus, vegetable crops etc.) was inspected for foliar fluoride injury at sites immediately north and northeast of RMC, as well as at more remote locations. In addition, foliage was collected from exposed middle branches at the ten Manitoba maple tree sites $(1,2,3,6,7,8,9,20,21$, 33 ), and at the three red maple sites (south shore woodlot west of bridge, south shore woodlot east of bridge, and N. Point), that were sampled in previous years. In 1993, Manitoba maple foliage also was collected for analysis adjacent to a sumach observation site near the river to the south of Maple Site 3. Duplicate samples were collected at each site using standard procedures (see attached Figure 1).

The foliage samples were returned to the Phytotoxicology Laboratory. Here, the "unwashed" samples were oven-dried, ground and stored in glass jars. All samples were then submitted to the MOEE Laboratory Services Branch for fluoride analysis. The samples of Manitoba maple foliage also were analyzed for aluminum and sodium. 


\section{Foliage Samples Collected for Laboratory Examination}

Two samples were collected for histopathological examination because the injury was fluoride-like: 1) injured current-year needles from an Eastern white pine in the woodlot just east of the bridge, and 2) injured foliage from a black cherry at the Island's south shore to the west of the bridge. The samples were stored in F.A.A. preserving fluid and returned to the Section's Histopathologist.

Two samples also were collected for pathological examination: 1) honeysuckle foliage with greyish-brown upper surface injury was collected near Maple Site 21, and 2) sumach foliage with marginal and interveinal necrosis/spots, cupping and savoying was collected from a site adjacent to the river, south of Maple Site 3. These samples were submitted to the Section's Pathologist.

\section{RESULTS OF VEGETATION ASSESSMENT PROGRAM}

\section{Visual .Observations}

On Cornwall Island in 1993 (August), foliar injury typical of fluoride toxicity was largely confined to the vicinity of the south shore bridge area, directly downwind and northeast of RMC. This includes residential areas in the vicinity of the Martin, A. Boots and N. Point properties (Figure 1).

In the south shore river area to the west of the bridge, fluoride-like injury on wild grape plants was light $(2-10 \%)$ to moderate $(11-35 \%)$ overall. The injury on wild grape plants elsewhere in the south shore bridge area was either trace $(<0-1 \%)$ or trace to light $(2-10 \%)$ overall. Also, in the area of the river to the west of the bridge, fluoride-like injury was observed on a young black cherry tree (light to moderate overall) and on a serviceberry shrub (trace overall). A mature black cherry in the area of the woodlot just east of the bridge also had trace injury. Fluoride-like necrosis was not observed on other cherry trees (pin, choke), or on plum trees (plot west of bridge), but as in previous years, cherry and plum foliage had missing marginal tissue symptomatic of fluoride damage.

As in previous surveys, mature staghorn sumachs in the area of the Island south shore (east and west of bridge) had varying degrees of foliar injury (marginal and/or interveinal necrosis, savoying, cupping) ranging from trace $(0-1 \%)$ to severe $(>35 \%)$ overall. Some sumachs to the neighbouring west of the bridge had severe injury overall, while other injured sumachs in the south shore bridge area had trace to moderate injury overall. The injury on sumach (usually considered intermediate in sensitivity to fluoride) often appeared too severe and out of context relative to the condition of neighbouring vegetation, including sensitive species (eg. wild grape, Manitoba maple, eastern white pine), to be entirely due to fluoride. In 1993, similar injury also was observed on sumach foliage more remote from RMC (near river, south of Maple Site 3). Only a few of the numerous sumachs at this site were affected. However, the pathological examination results, together with the fluoride level of the 
Manitoba maple foliage ( $33 \mathrm{ug} / \mathrm{g}$ ) collected in this area, did not implicate fluoride as the primary cause. Nevertheless, as the most severe and extensive sumach injury was observed in the south shore bridge area where foliar injury was most pronounced on other species, the possibility that RMC emissions had contributed to the injury in the south shore bridge area can not be ruled out.

Manitoba maple trees in the south shore bridge area, including Site 1, had either trace $(0-1 \%)$ or trace to light (2-10\%) fluoride-like foliar injury (tip or sinus necrosis) overall, with the most pronounced injury being observed on the L. Point property. However, as these and other Manitoba maple trees in the south shore bridge area had boxelder borer damage, which can result in foliar injury mimicking fluoride, Manitoba maples are not considered to be reliable indicators of fluoride exposure. Red/silver maple trees had trace brownish or blackish tip necrosis, including the red maple site in the west of bridge woodlot and the N. Point site. A few young silver maple trees on the A. Boots property also had some leaves with trace injury (blackish tips). The most severe injury was observed on red maple in the south shore woodlot just east of the bridge. At this site, brownish/blackish marginal necrosis was pronounced on several leaves, with the injury being moderate (11-35\%) to severe $(>35 \%)$ overall. The injured foliage had an abnormally elevated fluoride level $(90 \mathrm{ug} / \mathrm{g})$, an indication that fluoride had contributed to the injury. However, it is doubtful that fluoride was responsible for all of the injury here, as the foliar level of $90 \mathrm{ug} / \mathrm{g}$ was only marginally higher than that in the red maple foliage from the west of bridge woodlot $(68 \mathrm{ug} / \mathrm{g})$ and from the $\mathrm{N}$. Point site $(62 \mathrm{ug} / \mathrm{g})$, where only traces of injury were apparent. The red maple injury also appeared too severe in relation to the injury severity on other affected deciduous species in this area (eg. gladiolus, wild grape, black cherry, Manitoba maple) to be entirely due to fluoride.

Two mature Eastern white pine in the east of bridge woodlot (behind Martin banquet hall, just west of injured red maple) had reddish tip necrosis on current-year needles throughout the crown. The histology results implicated fluoride, but other causal factors may also be involved because other white pine in this woodlot and elsewhere, including those in the west of the bridge woodlot and red and scots pines on the slightly more remote N. Point property, displayed no obvious fluoride injury on current needles. One of the injured white pine had soil piled against the trunk, and a mature maple tree had toppled onto the side of the other injured pine resulting in damaged branches. These physical factors may have contributed to the foliar injury.

The inspections in the south shore bridge area to the northeast of RMC included gladiolus plants on the Martin property, cultivated grape at A. Boots, and vegetable crops on the L. Point and N. Point properties (A. Boots did not have a garden). The gladiolus foliage on the Martin property had light injury overall, and the cultivated grape vines on the A. Boots property had some leaves with trace $(0-1 \%)$ to light $(2-10 \%)$ fluoride-like injury (primarily tip injury). Garden crops appeared in normal condition. Vegetation, including wild grape and garden crops, also was inspected in the vicinity of the G. Charrow property immediately north of RMC, but no obvious fluoride injury was observed on vegetation in this area. 
The inspections more remote from RMC through to A. Lazore (East end of Island) revealed fluoride-like injury only on sensitive grape foliage. The wild and cultivated grape sites that were inspected to the northeast of RMC (beyond A. Boots and N. Point), including sites near the center and east end of the island (Elijah Benedict, Earny Benedict, A. Lazore), displayed either no injury or only a few leaves with inconsequential tip injury. The observations on sensitive wild grape foliage in 1993 revealed no major change in the degree and extent of fluoride-type foliar injury from the previous year.

The observations in the south shore bridge area in August 1993 are compared to the 1991 and 1992 injury ratings in Table 1. A few vegetation sites in 1993 had greater injury than in 1992 but, in most cases, the injury was not markedly different from 1992.

\section{Analytical Results}

\section{Fluoride}

The Manitoba maple fluoride results for 1993 are compared with previous survey data in Table 2. In August 1993, as in previous years, fluoride concentrations in Manitoba maple foliage were the highest at Site $1(155 \mathrm{ug} / \mathrm{g})$ in the south shore bridge area and sharply decreased with increasing distance from RMC. In 1993, fluoride levels were increased over 1992 levels at all but one of the ten Manitoba maple sites. However, at most sites, including Site 1, the fluoride concentration was only marginally higher than in 1992, with the level at Site $1(155 \mathrm{ug} / \mathrm{g})$ being amongst the lowest detected at this site. Since 1980, August fluoride levels at Site 1 have ranged from a low of $135 \mathrm{ug} / \mathrm{g}$ (1992) to a high of $389 \mathrm{ug} / \mathrm{g}$ (1984). The fluoride mean for all common Manitoba maple sites also was marginally higher in 1993 (39 $\mathrm{ug} / \mathrm{g}$ ) compared to the 1992 mean $(31 \mathrm{ug} / \mathrm{g}$ ), which was the lowest detected since 1980. Since 1980 , the mean for all common sites has ranged from a low of $31 \mathrm{ug} / \mathrm{g}$ (1992) to a high of 92 ug/g (1984).

In 1993, seven of the ten Manitoba maple sites had a foliar fluoride concentration exceeding the Phytotoxicology Section Upper Limit of Normal (ULN) rural guideline of 15 ug/g. This compares to five sites in both 1991 and 1992. All three red maple sites, similar to previous years, also exceeded the rural ULN. The highest level detected in 1993 (155 ug/g Site 1) was about ten times the rural ULN.

The three red maple sites in the vicinity of the south shore bridge area also had a slightly higher fluoride level in 1993 compared to 1992 (Table 3). The red maple at the east of bridge woodlot site (northeast of RMC) had the highest level $(90 \mathrm{ug} / \mathrm{g})$, as in previous years. Since 1982, fluoride levels in red maple foliage from the two south shore woodlots have ranged from a low of $22 \mathrm{ug} / \mathrm{g}$ (1985) to a high of $278 \mathrm{ug} / \mathrm{g}$ (1984).

Figure 2 illustrates the fluoride concentration at Site 1 from 1972 to 1993 . Foliar fluoride concentrations declined abruptly in 1978. Since 1978 and up to 1993 the concentrations have fluctuated both up and down but there has not been a consistent trend 
towards either an increase or a decrease in fluoride contamination at this site. In short, at Site 1, which historically has had the highest fluoride levels, there has not been an improvement in air quality since about 1978 .

\section{Aluminum and Sodium}

The aluminum and sodium results for the Manitoba maple sites are compared to previous survey data in Tables 4 and 5, respectively. As with fluoride, the highest foliar concentrations of aluminum (270 ug/g) and sodium (155 ug/g) were detected at Site 1 in the south shore bridge area to the northeast of RMC.

In 1993, half the sites had higher aluminum concentrations and half had lower concentrations, compared to 1992. The common Manitoba maple sites also had a slightly lower mean in 1993 (102 ug/g) compared to 1992 (107 ug/g). Since 1980, August aluminum concentrations at Site 1 have ranged from a low of $91 \mathrm{ug} / \mathrm{g}(1989)$ to a high of $420 \mathrm{ug} / \mathrm{g}$ (1992). The mean for all common sites has ranged from $44 \mathrm{ug} / \mathrm{g}$ (1989) to $145 \mathrm{ug} / \mathrm{g}$ (1980). Similar to previous years, none of the sites exceeded the rural ULN for aluminum (500 ug/g).

Foliar sodium concentrations at most sites ( 7 of 10 sites) were decreased or unchanged in 1993 compared to 1992. The level at Site 1 (155 ug/g) was amongst the lowest detected since 1980. The 1993 mean (66 ug/g) of common collection sites also decreased from 1992 (74 ug/g) and was similar to the low 1987 mean $(65 \mathrm{ug} / \mathrm{g})$. As in previous years, most sites exceeded the rural ULN for sodium (50 ug/g). The sodium level at Site $1(155 \mathrm{ug} / \mathrm{g}$ ) was about three times the rural ULN.

\section{Histopathological and Pathology Results}

Results of the histopathological examination of the injured current-year Eastern white pine needles (woodlot east of bridge) and of the injured black cherry foliage (south shore west of bridge) revealed that the injury in both cases was typical of fluoride.

The pathological examination of the injured sumach foliage (south shore, south of maple Site 3) revealed that a leaf spot disease (Phyllosticta sp.) had contributed to the interveinal spots/necrosis on the leaves. The brownish surface scorch on honeysuckle foliage (south shore, west of bridge) was attributed to leafminer injury, but the species was not identified.

\section{METEOROLOGICAL ASPECTS}

The wind data in 1993, as in 1992, was obtained from the Airport at Massena, New York. The rainfall data was obtained from the City of Cornwall Climate station rather than from the Ontario Hydro Climate Station (west of Cornwall), which has been slow to report the rainfall data in recent years. Massena and the City of Comwall are on opposite sides of the river across from Cornwall Island. 
The wind data (Table 6) shows the percentage of time wind was blowing from the south, south southwest, southwest and west southwest during June through August in 1993, compared to 1991 and 1992. These winds are primarily responsible for carrying RMC emissions onto Cornwall Island. Table 6 shows that there was an overall slight increase in wind from these directions in 1993 (35\%) compared to both 1991 (29\%) and 1992 (32.5\%).

Within limits, rain can also influence fluoride concentrations in vegetation. Rain can remove fluoride, especially of the particulate type, through foliar rinsing. Rain-washed foliage could be a factor in this survey because RMC emits sodium aluminum fluorosilicate as a particulate, in addition to gaseous hydrogen fluoride. This washing action can be reflected in the analytical results wherein years with high rainfall are expected to have lower fluoride concentrations if other factors are held constant. Conversely, dry years should be associated with higher fluoride values. The rainfall data (June through August) obtained from the City of Cornwall station (Table 7) shows that there was less rainfall and fewer days with rain during June through August in 1993 compared to 1992. This reduction in rainfall and the increase in south to southwest winds likely contributed to the increased fluoride concentrations in vegetation in 1993. An increase in emissions from RMC (not confirmed) also could have contributed.

Ambient fluoride monitoring on the island was not conducted by Environment Canada in 1992 or 1993 . Traditionally these data have been used to corroborate Phytotoxicology data.

\section{SUMMARY OF 1992 SURVEY FINDINGS} follows:

The main findings of the 1993 survey on Cornwall Island can be summarized as

1) RMC emissions during 1993 resulted in elevated levels of fluoride, aluminum and sodium in vegetation, particularly at Site 1 in the south shore bridge area (northeast of RMC). Fluoride levels in vegetation, similar to previous years, displayed a decreasing pattern with increasing distance from RMC.

2) Fluoride levels in maple foliage increased slightly in 1993 over 1992. This was due, in part, to an increase in south and southwest winds and a slight reduction in rainfall in 1993. In spite of the slight increase in fluoride contamination, the fluoride level at Site 1 and the mean for all common Manitoba maple sites were amongst the lowest detected. The level of sodium at Site 1 and the mean for 1993 also were amongst the lowest detected.

3) The Phytotoxicology Section rural Upper limit of Normal (ULN) guideline for fluoride in tree foliage $(15 \mathrm{ug} / \mathrm{g})$ was exceeded at 10 of the 13 regular maple sites, compared to 8 sites in 1991 and 1992. The rural sodium ULN (50 ug/g) was exceeded at 7 Manitoba maple sites. Similar to previous years, the ULN for aluminum was not exceeded, although an aluminum concentration gradient relative to RMC was evident. 
4) Fluoride-like injury on vegetation, as in previous years, was generally confined to the south shore bridge area of Cornwall Island. A few vegetation sites in 1993 had greater injury than in 1992 but, in most cases, the injury was not markedly different from 1992. Sensitive wild grape foliage in 1993 revealed no major change in the degree and extent of fluoride-type foliar injury from the previous year.

In conclusion, concentrations of fluoride in vegetation on Cornwall Island were increased slightly in 1993 over 1992. As in previous years, the highest degree of foliar contamination and most adverse vegetation injury were confined to the south shore bridge area to the northeast of RMC. With few exceptions, the vegetation injury in this area was not markedly different from 1992. Weather conditions could have contributed to the slight increase in fluoride contamination of vegetation on Cornwall Island in 1993. On average, the trend in foliar fluoride concentrations at Site 1 (traditionally the most contaminated site) has not changed (neither improved nor deteriorated) since 1978. 


\begin{tabular}{|c|c|c|c|c|c|}
\hline \multirow[t]{2}{*}{ Specles } & \multirow{2}{*}{ Foliar Injury Description } & \multirow[t]{2}{*}{ General Location } & \multicolumn{3}{|c|}{ Overall Severity } \\
\hline & & & 1991 & 1992 & 1993 \\
\hline \multirow[t]{2}{*}{ Black Cherry } & \multirow[t]{2}{*}{ Reddish-brown marginal and/or tip necrasis } & Near River (1) & L & L-M & L-M \\
\hline & & Woodlat Area (2) & NR & NI & $T$ \\
\hline \multirow[t]{3}{*}{ Pin Cherry } & \multirow[t]{3}{*}{ Reddish-tan marginal and/or tip necrosis } & Woodlat Area (1) & NI-T & $\mathrm{NI}$ & $\mathrm{NI}$ \\
\hline & & River Area (1) & $T$ & $T$ & NI \\
\hline & & River Area (2) & $T$ & NI & $\mathrm{NI}$ \\
\hline \multirow[t]{4}{*}{ Manitoba Maple } & \multirow{4}{*}{$\begin{array}{l}\text { Reddish-tan marginal necrasis and/ar tip or } \\
\text { sinus necrosis }\end{array}$} & Site $21(1)$ & NI & $\dot{N I}$ & $\mathrm{NI}-\mathrm{T}$ \\
\hline & & Site $1(2)$ & $L-M$ & $\mathbf{T}$ & $\mathrm{T}$ \\
\hline & & Site $33(2)$ & $T$ & NI & NI-T \\
\hline & & L. Point (2) & $T-L^{\bullet}$ & $T$ & $T-L$ \\
\hline \multirow{4}{*}{$\begin{array}{l}\text { Red/ } \\
\text { Silver Maple }\end{array}$} & \multirow[t]{4}{*}{ Brownish-black marginal and/or tip necrosis } & Woodlat (1) & $T$ & $T$ & $T$ \\
\hline & & Woadlot (2) & $L$ & $T$ & M-S \\
\hline & & N. Point (2) & $\mathrm{T}$ & $\mathrm{NI} \cdot$ & NI-T \\
\hline & & A. Boots (2) & $\mathbf{T}$ & $T$ & NIIT \\
\hline Plum & Reddish-brown marginal and/or tip necrosis & L. Point (2) & $T-L^{*}$ & $\mathrm{NI}$ & NI \\
\hline Servicebeiry & Reddish-brown marginal and/or tip necrosis & River Area (1) & $T-L$ & $L$ & $T$ \\
\hline \multirow{5}{*}{$\begin{array}{l}\text { Stagharn } \\
\text { Sumach". }\end{array}$} & \multirow{5}{*}{$\begin{array}{l}\text { Red-brown to blackish marginal-interveinal } \\
\text { injury, savoying, cupping, broken margins }\end{array}$} & Plum Plat Area (1) & $T-L^{*}$ & L-M & L-S \\
\hline & & Woodlot Area (1) & $L$ & $L$ & T-S \\
\hline & & River Area (1) & $T-L$ & L-S & $M$ \\
\hline & & Waadlot Area (2) & NR & $L$ & L-M \\
\hline & & River Area (2) & $L-M$ & $T-M$ & L-M \\
\hline \multirow[t]{7}{*}{ Wild Grape } & \multirow[t]{7}{*}{ Reddish-brown marginal and/or tip necrosis } & Woodiat Area (1) & $T-L$ & $T-L$ & $T-L$ \\
\hline & & River Area (1) & $L$ & $T-L$ & $L-M$ \\
\hline & & Woodlot Area (2) & $T-L$ & $T$ & NI-T \\
\hline & & River Area (2) & $T=L^{*}$ & $L$ & $T$ \\
\hline & & N. Paint (2) & $T-L$ & $\mathrm{~T}$ & $T$ \\
\hline & & A. Boots Area (2) & $T-L$ & $T$ & $T$ \\
\hline & & Custams Area (1) & $\mathrm{T}$ & $\mathrm{NI}-\mathrm{T}$ & NI-T \\
\hline Cultivated Grape & Reddish-brawn marginal and/or tip necrosis & A. Boots (2) & T & $\mathrm{T}$ & $T-L$ \\
\hline \multirow[t]{2}{*}{ Gladialus } & \multirow[t]{2}{*}{ Reddish-brawn marginal injury } & Martin Property (2) & NP & NP & $\mathbf{L}$ \\
\hline & & N. Paint (2) & $\mathbf{T}$ & $T$ & NP \\
\hline Eastern White Pine & Reddish-brown tip necrasis & Woodlat (2) & T & NI & $L-M$ \\
\hline
\end{tabular}




\begin{tabular}{|c|c|c|c|c|c|c|c|c|c|c|c|}
\hline \multirow{3}{*}{ Year } & \multicolumn{11}{|c|}{ Concentration of Fluoride in Unwashed Foliage } \\
\hline & \multicolumn{11}{|c|}{ Sampling Location (see Figure 1) } \\
\hline & $\begin{array}{c}\text { Site } \\
1\end{array}$ & $\begin{array}{c}\text { Site } \\
33\end{array}$ & $\begin{array}{c}\text { Site } \\
3\end{array}$ & $\begin{array}{c}\text { Site } \\
6\end{array}$ & $\begin{array}{c}\text { Site } \\
7\end{array}$ & $\begin{array}{c}\text { Site } \\
21\end{array}$ & $\begin{array}{c}\text { Site } \\
2\end{array}$ & $\begin{array}{c}\text { Site } \\
8\end{array}$ & $\begin{array}{c}\text { Site } \\
9\end{array}$ & $\begin{array}{c}\text { Site } \\
20\end{array}$ & Mean \\
\hline 1972 & 451 & $N R$ & $N R$ & 317 & 90 & $N R$ & $N R$ & 30 & NR & $N R$ & NC \\
\hline 1973 & 597 & $N R$ & NR & 244 & NR & $N R$ & $N R$ & $N R$ & $N R$ & NR & NC \\
\hline 1974 & 516 & $N R$ & $N R$ & 98 & 79 & $N R$ & $N R$ & $\cdot 76$ & NR & $N R$ & NC \\
\hline 1975 & 1171 & $N R$ & NR & 235 & 100 & $N R$ & $N R$ & 60 & 66 & NR & NC \\
\hline 1976 & 550 & $N R$ & 122 & 114 & 116 & $N R$ & 123 & 29 & 31 & $N R$ & $N C$ \\
\hline 1977 & 750 & $N R$ & 217 & 56 & 37. & $N R$ & 138 & 45 & 14 & $N R$ & $N C$ \\
\hline 1978 & 193 & $N R$ & 32 & 22 & 23 & $N R$ & 17 & 15 & 7 & 6 & 39 \\
\hline 1979 & 197 & $N R$ & 57 & 32 & 21 & $N R$ & 31 & 21 & 15 & 15 & 49 \\
\hline 1980 & 143 & $N R$ & 60 & 23 & 15 & $N R$ & 10 & 8 & 5 & 3 & 33 \\
\hline 1981 & 192 & $N R$ & 86 & 71 & 64 & $N R$ & 50 & 18 & 26 & 29 & 67 \\
\hline 1982 & 380 & NR & 70 & 28 & 15 & $N R$ & 25 & 12 & 18 & 17 & 71 \\
\hline 1983 & 293 & 123 & 97 & 48 & 37 & $N R$ & 57 & 27 & 19 & 31 & 76 \\
\hline 1984 & 389 & 117 & 113 & 57 & 39 & $N R$ & $63^{\circ}$ & 23 & 14 & 41 & 92 \\
\hline 1985 & 337 & 71 & 92 & 48 & 33 & $N R$ & 50 & 32 & 22 & 26 & 80 \\
\hline 1986 & 159 & 49 & 48 & 25 & 18 & 69 & 27 & 19 & 17 & 19 & 42 \\
\hline 1987 & 149 & 48 & 59 & 44 & 24 & 74 & 48 & 18 & 14 & 22 & 47 \\
\hline 1989 & 140 & 55 & 51 & 15 & 13 & 76 & 35 & 10 & 8 & 15 & 36 \\
\hline 1991 & 375 & 78 & 41 & 29 & 14 & 93 & 14 & 7 & 9 & 15 & 63 \\
\hline 1992 & 135 & 47 & 26 & 26 & 15 & 70 & 15 & 11 & 6 & 10 & 31 \\
\hline 1993 & 155 & 70 & 40 & 20 & 21 & 99 & 37 & 14 & 12 & 12 & 39 \\
\hline \multicolumn{12}{|c|}{$\begin{array}{l}\text { - ug/g. dry weight, mean of duplicate (1987 to 1993) or triplicate (1975 to 1979; } 1983 \text { to 1986) samples and analysis. A } \\
\text { single sample per site was collected from } 1972 \text { to } 1974 \text { and from } 1980 \text { to } 1982 . \\
\text { - Mean of Common Sites, excluding Sites } 21 \text { and } 33 \text {. } \\
\text { NR - No result, samples not collected/analysis not conducted. } \\
\text { NC - Mean nol calculated because of fewer common sites. } \\
\text { Note a: Shaded values exceed Phytotoxicology Section Upper Limit of Normal (ULN) rural guideline of } 15 \mathrm{ug} / \mathrm{g} \text { (see } \\
\text { appendix). } \\
\text { Note b: Samples have been analyzed by ion selective electrode since 1982. Alkali fusion method was used prior to } 1982\end{array}$} \\
\hline
\end{tabular}




\begin{tabular}{|c|c|c|c|}
\hline \multirow{3}{*}{ Year } & \multicolumn{3}{|c|}{ Foliar Fluoride Concentration* } \\
\hline & \multicolumn{2}{|c|}{ Woodlots at South Shore of Island } & \multirow{2}{*}{$\begin{array}{l}\text { More Distant } \\
\text { N. Point Property }\end{array}$} \\
\hline & West of Bridge & East of Bridge & \\
\hline 1982 & 118 & 99 & NR \\
\hline 1983 & NR & NR & NR \\
\hline 1984 & 134 & 278 & 172 \\
\hline 1985. & 22 & 139 & 88 \\
\hline 1986 & 37 & 43 & 42 \\
\hline 1987 & 59 & 109 & 81 \\
\hline 1988 & NR & NR & NR \\
\hline 1989 & 48 & 64 & 44 \\
\hline 1990 & NR & NR & NR \\
\hline 1991 & 34 & 195 & 62 \\
\hline 1992 & 39 & 57 & 34 \\
\hline 1993 & 68 & 90 & 62 \\
\hline \multicolumn{4}{|c|}{$\begin{array}{l}\text { - ug/g, dry weight, mean of triplicate (1984) or duplicate (1985-1993) samples. Single samples were } \\
\text { collected in } 1982 \text {. } \\
\text { NR - No results, samples not collected. } \\
\text { Note: Shaded values exceed Phytoloxicology Section Upper Limit of Normal rural guideline of } 15 \mathrm{ug} / \mathrm{g} \text {. }\end{array}$} \\
\hline
\end{tabular}




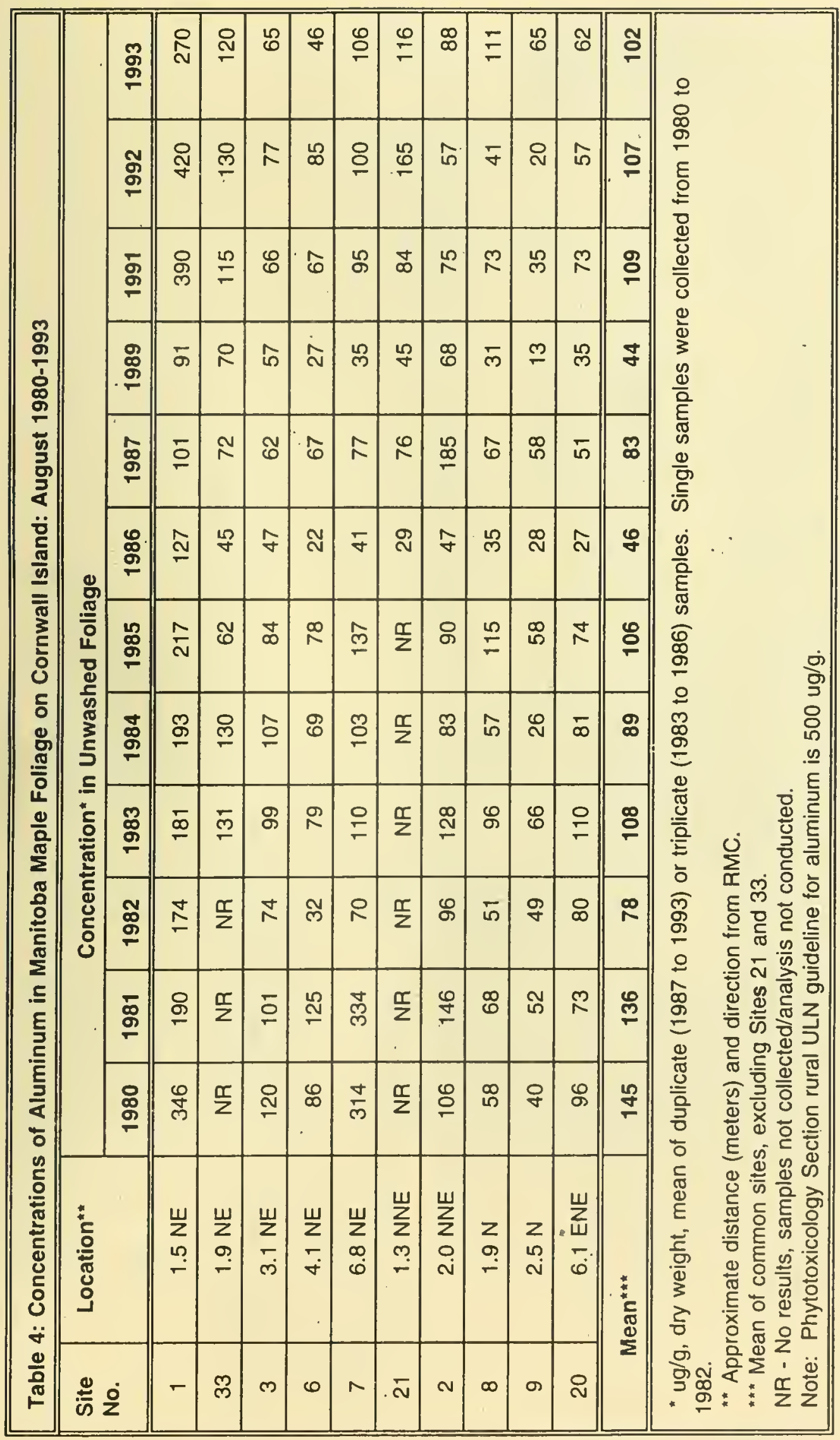




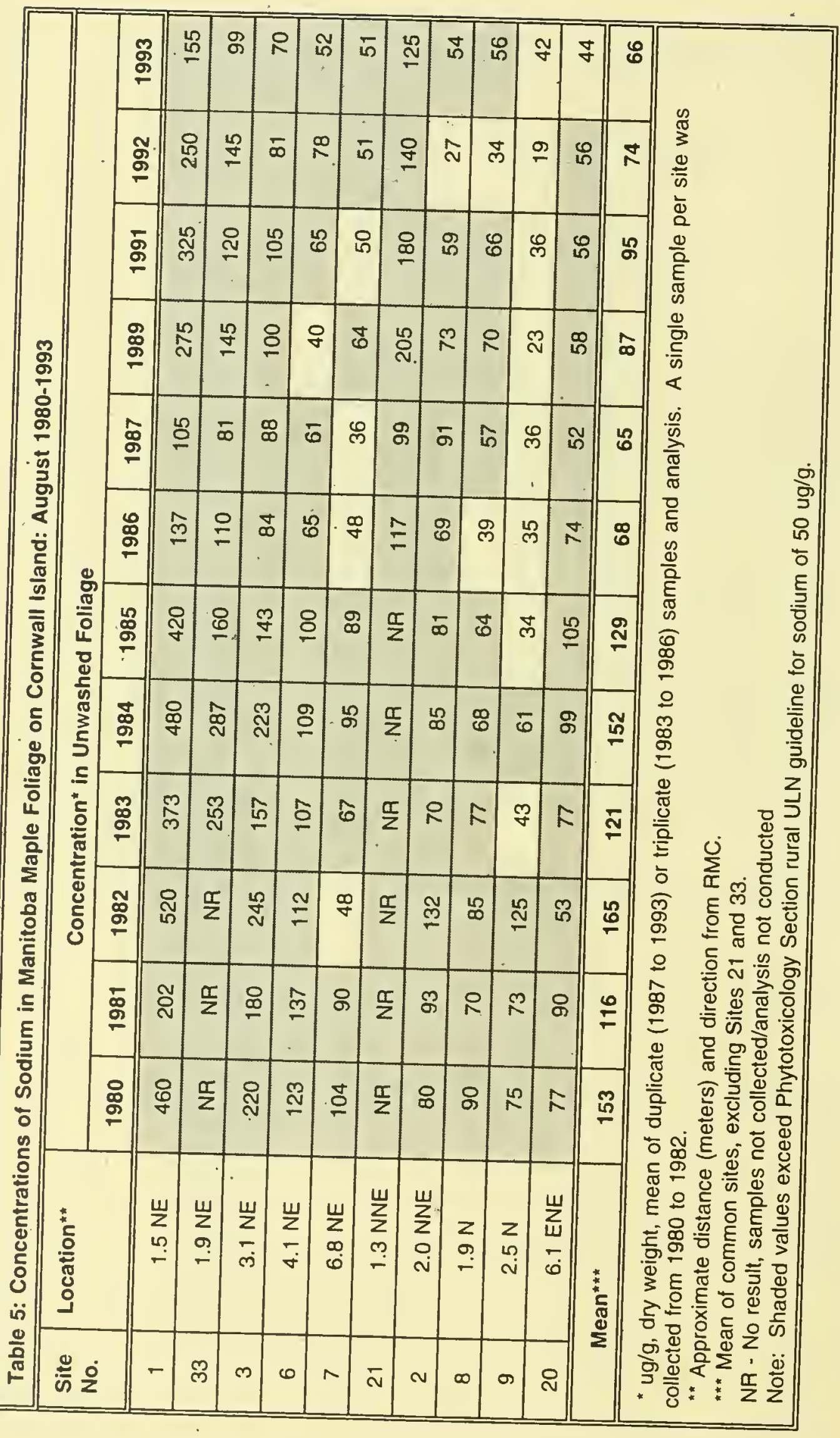




\begin{tabular}{|c|c|c|c|}
\hline \multicolumn{4}{|c|}{$\begin{array}{l}\text { Table 6: Percentage (\%) of Time Wind was } \\
\text { Blowing from South and Southwest Directions } \\
\text { at Massena Airport during June to August, } \\
1991 \text { to } 1993 .\end{array}$} \\
\hline Direction & 1991 & 1992 & 1993 \\
\hline South & 0.8 & 1.1 & 2.3 \\
\hline South Southwest & 1.3 & 2.3 & 3.2 \\
\hline Southwest & 6.4 & 6.2 & 8.6 \\
\hline West Southwest & 20.5 & 22.9 & 20.9 \\
\hline Total & 29 & 32.5 & 35 \\
\hline \multicolumn{4}{|c|}{$\begin{array}{l}\text { From June through to and including date of } \\
\text { foliage collection: } 1991 \text { - Aug. 22; } \\
1992 \text { and } 1993 \text { - Aug. } 11 \text {. }\end{array}$} \\
\hline
\end{tabular}

\begin{tabular}{|c|c|c|c|c|c|c|}
\hline \multirow[t]{2}{*}{ Month } & \multicolumn{2}{|c|}{1992} & \multicolumn{2}{|c|}{1993} & \multicolumn{2}{|c|}{ Normals** } \\
\hline & Total Rain & Frequency & Total Rain & Frequency & Total Rain & Frequency \\
\hline June & 73 & 13 & 113 & 14 & 81.8 & 11 \\
\hline July & 117 & 15 & 82 & 11 & 84.3 & 10 \\
\hline August" & 40 & 6 & 19 & 7 & $97^{* 1 *}$ & $11^{m=}$ \\
\hline Total & $230(7)$ & 34 & $214(8)$ & 32 & NA & NA \\
\hline \multicolumn{7}{|c|}{$\begin{array}{l}\text { "Through to and including date of regular maple foliage collection (August 11) } \\
\text { ** Painfall normals taken from Canadian Climate Normals (1961-1990), Atmospheric Environment } \\
\text { Service, Environment Canada, Toronto. } \\
\text { "* All of August } \\
\text { () Number of days with rain during two week period prior to and including date of foliage } \\
\text { collection. } \\
\text { NA Not available. }\end{array}$} \\
\hline
\end{tabular}




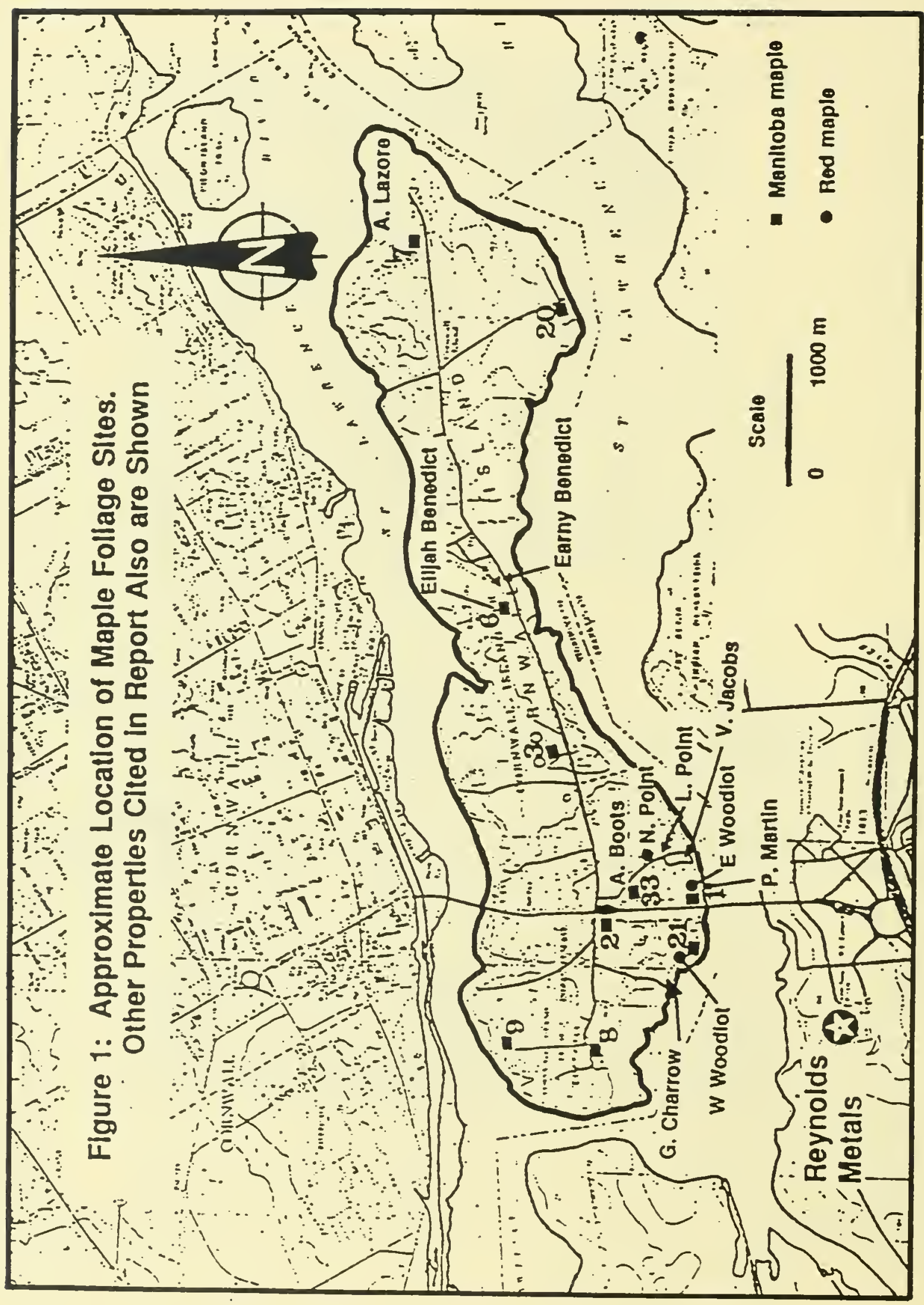




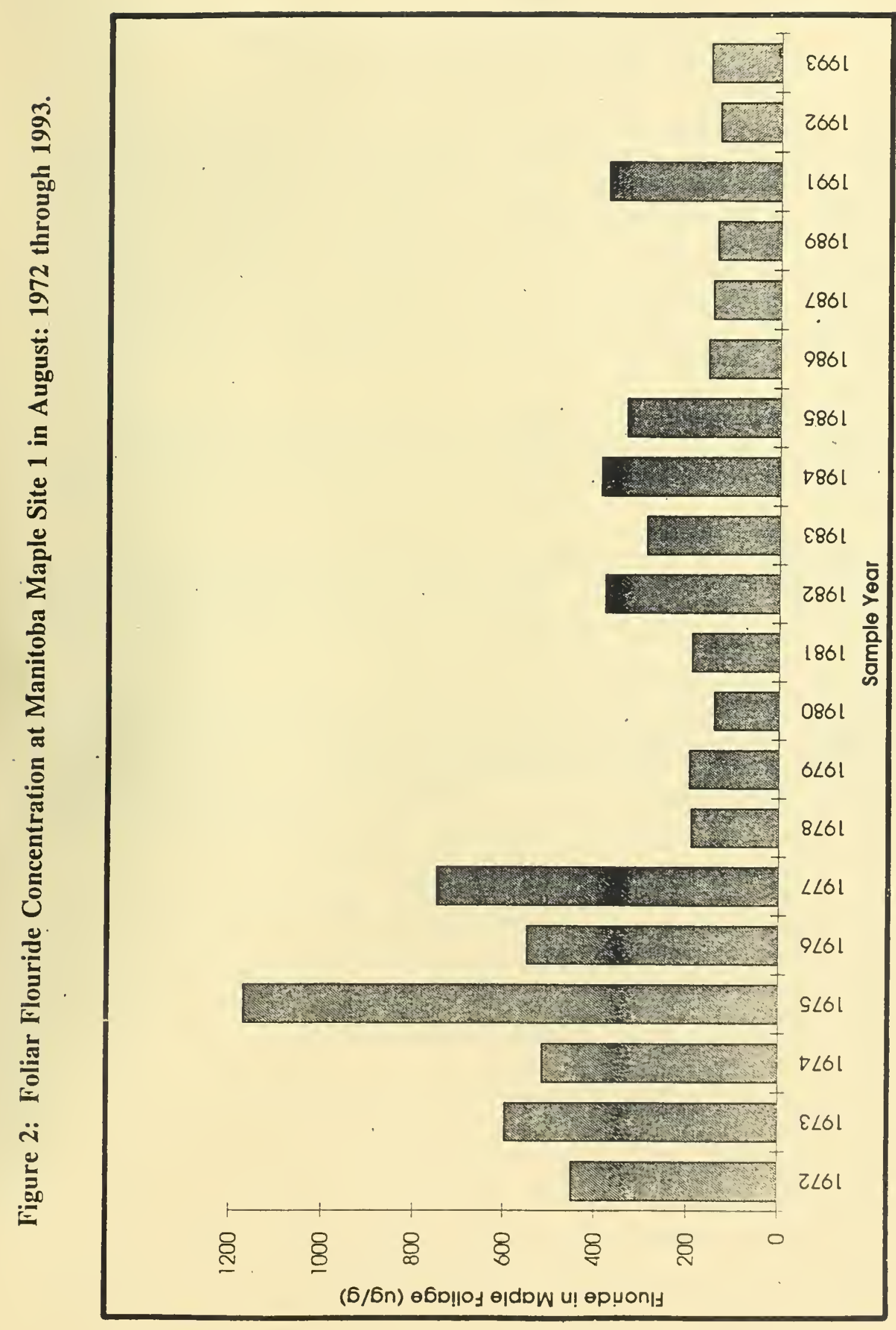





\section{Appendix \\ Derivation and Significance of the MOEE Phytotoxicology \\ "Upper Limits of Normal" Contaminant Guidelines.}

The MOEE Upper Limits of Normal (ULN) contaminant guidelines represent the expected maximum concentration in surface soil, foliage (trees and shrubs), grass, moss bags, and snow from areas in Ontario not exposed to the influence of a pollution source. Urban ULN guidelines are based on samples collected from urban centres, whereas rural ULN guidelines were developed from nonurbanized areas. Samples were collected by Phytotoxicology staff using standard sampling procedures (reference: Ontario Ministry of the Environment. 1989. Ontario Ministry of the Environment "Upper Limit of Normal" Contaminant Guidelines for Phytotoxicology Samples. Phytotoxicology Section, Air. Resources Branch: Technical Support Sections NE and NW Regions, Report No. ARB-138-88-Phyto. ISBN: 0-7729-5143-8.). Chemical analyses were conducted by the MOEE Laboratory Services Branch.

The ULN is the arithmetic mean plus three standard deviations of the suitable background data for each chemical element and parameter. This represents $99 \%$ of the sample population. This means that for every 100 samples that have not been exposed to a pollution source, 99 will fall within the ULN.

The ULNs do not represent maximum desirable or allowable limits. Rather, they are an indication that concentrations that exceed the ULN may be the result of contamination from a pollution source. Concentrations that exceed the ULNs are not necessarily toxic to plants, animals, or people. Concentrations that are below the ULNs are not known to be toxic.

ULNs are not available for all elements. This is because some elements have a very large range in the natural environment and the ULN, calculated as the mean plus three standard deviations, would be unrealistically high. Also, for some elements, insufficient background data is available to confidently calculate ULNs. The MOEE Phytotoxicology ULNs are constantly being reviewed as the background environmental data base is expanded. This will result in more ULNs being established and may amend existing ULNs. 

